\title{
The impact of insecticides management linked with resistance expression in Anopheles spp. populations
}

\author{
O impacto do manejo de inseticidas relacionado \\ com a expressão de resistência em populações de Anopheles spp.
}

Guilherme Liberato da Silva ${ }^{1}$

Thiago Nunes Pereira ${ }^{1}$

Noeli Juarez Ferla ${ }^{2}$

Onilda Santos da Silva ${ }^{1}$

\footnotetext{
${ }^{1}$ Departamento de Microbiologia, Imunologia e Parasitologia, Universidade Federal do Rio Grande do Sul. R. Sarmento Leite 500, Centro Histórico. 90050-170 Porto Alegre RS Brasil. onilda.silva@ufrgs.br ${ }^{2}$ Laboratório de Acarologia, Museu de Ciências Naturais, Centro Universitário UNIVATES. Lajeado RS Brasil.
}

\begin{abstract}
The resistance of some species of Anopheles to chemical insecticides is spreading quickly throughout the world and has hindered the actions of prevention and control of malaria. The main mechanism responsible for resistance in these insects appears to be the target site known as knock-down resistance ( $k d r)$, which causes mutations in the sodium channel. Even so, many countries have made significant progress in the prevention of malaria, focusing largely on vector control through long-lasting insecticide nets (LLINs), indoor residual spraying and (IRS) of insecticides. The objective of this review is to contribute with information on the more applied insecticides for the control of the main vectors of malaria, its effects, and the different mechanisms of resistance. Currently it is necessary to look for others alternatives, e.g. biological control and products derived from plants and fungi, by using other organisms as a possible regulator of the populations of malaria vectors in critical outbreaks.
\end{abstract}

Key words Malaria, Anopheles, Knock-down resistance (kdr), Pesticides, Public Health.
Resumo A resistência de algumas espécies de Anopheles a inseticidas químicos está se espalhando rapidamente por todo o mundo e tem dificultado as ações de prevenção e controle da malária. O principal mecanismo responsável pela resistência nestes insetos parece ser o sítio-alvo conhecido como resistência knock-down resistance ( $k d r)$, que causa mutações no canal de sódio. Mesmo assim, muitos países fizeram progressos significativos na prevenção da malária, concentrando-se em grande parte no controle do vetor através redes inseticidas de longa duração (RILD), e de pulverização residual interna (PRI) de inseticidas. O objetivo desta revisão é contribuir com informações sobre os inseticidas mais aplicados para o controle dos principais vetores da malária, seus efeitos, e os diferentes mecanismos de resistências. Atualmente é necessário olhar para outras alternativas, como por exemplo, controle biológico e produtos derivados de plantase fungos, pela utilização de outros organismos como um possivel regulador de populações de vetores da malária em surtos críticos.

Palavras-chave Malária, Anopheles, Knockdown resistance $(k d r)$, Pesticidas. Saúde Pública 


\section{Background}

According to the World Health Organization (WHO), Malaria kills over a million people per year and other 3.2 billion people are living in areas at risk. Over $80 \%$ of deaths occur in Africa, where approximately $66 \%$ of this population is at risk area ${ }^{1}$. In the Americas, $14 \%$ of the population is at risk of transmission. Since the year 1990, the number of malaria cases reported in South and Central America and the Caribbean remain relatively low, however there is a risk of malaria transmission in nine countries that are part of the Amazon region and in eight countries in Central America and the Caribbean ${ }^{1}$.

Malaria is a disease caused by Plasmodium species which are transmitted by several species of Anopheles mosquitoes. There are approximately 400 species of Anopheles world-wide and of these about 50 species are exclusive vectors of human malaria ${ }^{2,3}$. The most important vectors in Sub-Saharan Africa and the most efficient malaria vectors world-wide belong to the Anopheles gambiae Complex. In this complex, A. gambiae and Anopheles arabiensis are the most important vectors of Plasmodium falciparum (the most severe malarial pathogen) in Africa. At level of Americas, Anopheles darlingi is one of the most important malaria vectors ${ }^{4}$, occurring mainly in Amazon region and showed high degree of variability in behavioral traits and capable of maintaining a relatively high transmission of malaria even when found in low densities ${ }^{5,6}$. This makes it difficult to predict the impact of ongoing changes in the environment on the mosquito populations. Due to their anthropophilic behavior and physiological feasibilities, they possess a higher vector capacity than other closely related sibling species with no or low vector capacity. Falavigna-Guilherme et al. ${ }^{4}$ carry out the reported autochthonous cases of malaria after construction of the Itaipu Hydroelectric in Foz do Iguacu. The impact of dams and irrigated schemes Anopheles populations has been elucidated by Sanchez-Ribas et al. ${ }^{7}$ revealing the proliferation of Anopheles species in anthropogenic environments.

Apparently, pathogen/parasite and vector (mosquito) either adapted to each other during the course of evolution, resulting in coexistence, or the pathogen/parasite was repelled ${ }^{8}$. Anopheles gambiae has been considered the most anthropophilic species, followed by A. arabiensis, Anopheles melas, and Anopheles merus. However, host preference likely varies considerably within species owing to population structure and environ- mental conditions, and reports of host preference also vary depending upon the methods used to measure this poorly defined behavior ${ }^{9-11}$.

In an effort to malaria transmission reduction, some countries have implemented indoor residual spraying (IRS) and universal distribution of insecticide-treated nets ITNs in combination in years ${ }^{12,13}$. Many countries have made significant progress in preventing malaria by focusing largely on vector control through long-lasting insecticidal nets (LLINs) and indoor residual spraying (IRS) of insecticides and use of DDT has been compromised, not only because of resistance, but also because of its environmental effects $^{14,15}$. In areas with insecticide-susceptible mosquito populations, the insecticide on LLINs mitigates the loss of personal protection if the net becomes holed.

The reduction in disease burden of malaria in recent years has in large part been attributed to the massive scale up of the two main vector control interventions, LLINs and IRS, particularly in Africa south of the Sahara. A number of countries have deployed the two interventions in combination in an attempt to further reduce transmission $^{16}$.

However, both IRS and LLINs face the development of physiological resistance (against insecticide) and 'behavioural resistance' in mosquitoes, which can reduce effectiveness of these interventions and possibly reverse the gains made in reducing malaria morbidity ${ }^{17}$, but there are currently not enough data to determine the impact of resistance on the effectiveness of such combinations ${ }^{16}$. Maybe, IRS has some utility in areas with low resistance as part of an overall resistance management strategy aimed at preserving the effectiveness of pyrethroids ${ }^{16}$. Although such resistance may be inevitable with successful control programmes, new strategies need to be developed to mitigate development and spread of insecticide resistance and to preserve the efficacy of currently available insecticides and the effectiveness of malaria control interventions.

The aim of this review is to elucidate the Anopheles spp. literature about the mainly vector species of malaria disease, what insecticides are applied, their effects and the different mechanisms resistances arising in these species.

\section{Approach about Anopheles in agricultural fields}

Agricultural practices have significant influence on mosquito species diversity and abun- 
dance and that certain habitat characteristics favor production of malaria vectors. For example, the creation of fishponds basins and the development of market-gardening activities, which also serves as breeding sites, can increase drastically proliferation of Anopheles species, especially A. gambiae $^{18}$. These factors should be considered when implementing larval control strategies which should be targeted based on habitat productivity and water management ${ }^{19}$. There is evidence for direct relationship between irrigation development and increased malaria transmission $^{20,21}$. Rice fields have proved to be particularly well suited as larval sites for A. gambiae s.l.. Jarju et al. $^{22}$ showed that the treating rice fields close to the landward edge of the floodplains with larvicides would help to reduce transmission levels because demonstrates the human-made changes are exploited by anopheline mosquitoes resulting in increased malaria transmission.

\section{Insecticide resistance}

DDT (dichlorodiphenyltrichloroethane) and pyrethroids share the same mode of action on the insect nervous system, targeting the neuronal voltagegated sodium ion channels. Molecular characterizations have revealed that various mutations in the S1-S6 transmembrane segments of domain II of the sodium ion channel gene give rise to resistance to these insecticides ${ }^{23,24}$. Santolamazza et $a .^{25}$ reported the distribution of knock-down resistance mutations in A. gambiae molecular forms, and suggest that there is an impact of human activities on $k d r$ distribution in some samples. The different distribution of the two $k d r$ mutations between sympatric $\mathrm{M}$ and $\mathrm{S}$ populations could also reflect different ecological/behavioural traits between $\mathrm{M}$ and S-forms that might promote different exposure to insecticide selective pressures. For example, the M-form may be more adapted to urbanized, man-influenced ecological settings, whereas the S-form tends to prevail in rural settings where a use of insecticides for agricultural purposes is expected to be greater ${ }^{26,27}$.

Vector resistance to pyrethroids has been reported in African continent ${ }^{28-33}$ and China ${ }^{34}$. Many studies conducted in Africa have reported the presence of the $k d r$ gene, associated with the "knock-down resistance" mechanism, in A. gambiae complex species ${ }^{35-39}$. The development and spread of malaria vector resistance to insecticides has been attributed to the intensive use of insecticides in agriculture ${ }^{40,41}$. To date, the resistance of
Anopheles species to the four families of insecticides available for public health use (organochlorines, organophosphates, carbamates, and pyrethroids) is a genuine concern throughout Afri$\mathrm{ca}^{18,42-44}$. In Anopheles gambiae sensu stricto, there are two point mutations at the voltage-gated sodium channel gene confer knockdown resistance $(k d r)$ to DDT and pyrethroids insecticides.

Martinez-Torres et al. ${ }^{45}$ identified a Leucine-Phenylalanine substitution at position L1014F of the gene encoding the S6 transmembrane segment of domain II of the sodium channel, in laboratory strains derived from field resistant samples of Burkina Faso and Ivory Coast. A second mutation, a Leucine-Serine substitution at the same codon (L1014S), has been identified in a colony derived from specimens from Ken$\mathrm{ya}^{30}$. Kabula et al. ${ }^{46}$ observed the co-occurrence of L1014S and L1014F mutations associated to pyrethroids resistance and maybe this phenomenon is spreading in vector malaria populations. Field surveys revealed a widespread distribution of the $1014 \mathrm{~F}$ allele in West Africa ${ }^{28,47}$. In addition, significant differences were found in the frequency of this allele between two molecular forms, denoted $\mathrm{M}$ and $\mathrm{S}$, that are considered units of incipient speciation within A. gambiae ${ }^{26}$. These forms are characterized by sequence differences in transcribed and non-transcribed spacers of the ribosomal DNA. The S-form is the most widespread throughout Sub-Saharan Africa while the M-form is mostly confined to the West part of Africa, from Senegal to Angola. In general, the $1014 \mathrm{~F}$ allele is common in the S-form but rare in the M-form, even when populations of both forms occur in sympatry ${ }^{26,48}$. In the few M-form populations where it has been found, sequencing analysis of the upstream intron- 1 of the $k d r$ locus showed that the $1014 \mathrm{~F}$ allele apparently occurred through introgression with the S-form ${ }^{49}$. Recent surveys have reported the co-occurrence of both $1014 \mathrm{~F}$ and $1014 \mathrm{~S}$ alleles in localities of Gabon, Cameroon and Uganda ${ }^{37,50}$.

The distribution and frequency of these mutations poses serious questions about the sustainability of insecticide-based vector control programs. This is particularly evident when one considers that pyrethroids are the only insecticides recommended by the World Health Organization for insecticide-treated materials and that DDT is being re-introduced for malaria control in several countries ${ }^{51}$. The pyrethroids produced a more immediate irritant effect than DDT ${ }^{52}$. Knowledge of the way $k d r$ resistance is evolving in A. gambiae is therefore of great epidemiological impor- 
tance. Lol et al. ${ }^{53}$ showed that molecular evidence suggests the presence of $k d r$-type resistance in field-collected Anopheles albimanus associated to mutations on the voltage-gated sodium channel (VGSC) gene. VGSC can be in many cases the responsible to resistance of pyrethroids.

Xu et al. ${ }^{54}$ discuss the diagnostic of insecticide resistance and showed how the sample collection and preparation methods affect insecticide susceptibility bioassay. Field-collected female adults consistently exhibited the highest monooxygenase and Glutathione-S-transferases activities, responsible by mechanism is metabolic detoxification of pyrethroids. Awolola et al. ${ }^{55}$ tested PermaNet $^{\oplus} 3.0$, known as insecticide synergist-combination long-lasting insecticidal net used to metabolic resistance when combined with $k d r$. The PermaNet ${ }^{\circledR} 3.0$ significantly reduced Anopheles gambiae densities per house and confirmed increased efficacy of PN 3.0 compared to the pyrethroid-only LLIN.

Pinto et al. ${ }^{56}$ genotyped the $k d r$ locus and sequenced the upstream intron-1 in samples of A. gambiae S-form, so their studies proved that selection through insecticide pressure will favor $k d r$ alleles and remove wild-type alleles. Therefore, the frequency of haplotypes carrying the wild-type allele will be lower than expected under neutrality, and so frequency need not reflect age.

Through these studies the $k d r$ mutations are not homogeneously distributed in the two molecular forms of A. gambiae (termed $\mathrm{M}$ and S), which are considered as incipient species. In fact in early studies, the absence of the $L 1014 F$ allele in the M-form was considered one of the major pieces of evidence for a severe restriction of gene flow between the two forms.

Ilboudo-Sanogo et al. ${ }^{57}$ reported malaria vector resistance to pyrethroids and DDT in five localities exposed to high insecticide pressure in Burkina Faso and assessed by PCR the frequency of the $k d r$ gene allele, associated with the "knockdown resistance" mechanism in A. gambiae and A. funestus. Thus, A. gambiae indicates a decrease in vector susceptibility to DDT in four localities included rural, suburban, and urban areas. The problem of physiological resistance against insecticides is more acute for LLINs than for IRS, as LLINs rely solely on pyrethroids, whereas IRS can be done with several classes of insecticides. There is evidence of increasing levels of pyrethroid resistance ${ }^{58}$ and corresponding decreases in the effectiveness of malaria control programmes that rely on pyrethroid-based interventions $s^{59}$.

Since, Briët et al. ${ }^{60}$ assessed the use of pyre- throids, Deltamethrin and Permethrin in LLINs, despite resistance being an important factor in reducing their effectiveness and showed that they are likely to be cost effective against malaria even in areas with strong pyrethroid resistance ${ }^{31}$. The insecticide susceptible mosquitoes can become extremely adapted your feeding behavior after LLINs implementation and occur the increase in frequency of $k d r$ L1014F genotype. Despite this, through the observations, Plasmodium falciparum prevalence and gametocyte rate in villagers decreased dramatically after LLINs deployment ${ }^{61}$. These authors support the view that it is important to pursue the use of LLINs in compliance with the WHO recommendations ${ }^{62}$.

In A. darlingi, Long-term DDT use resulted in a changed susceptibility of $A$. darlingi populations over time ${ }^{63}$. Indoor Residual Spraying (IRS) and Insecticide Treated Nets (ITNs) reduced intra-domiciliary vector densities ${ }^{64}$. ITNs for instance proved very successful against $A$. darlingi in southern Venezuela, where a reduction of 56\% of malaria cases was recorded in local indigenous populations after the introduction of lambdacyhalotrin- treated hammock nets ${ }^{65}$.There is strong evidence that $A$. darlingi may be insecticide resistant to deltamethrin, due to the low mortality in bioassays ${ }^{66}$. Anopheles arabiensis is a member of the Anopheles gambiae Giles complex and the third most important malaria vector mosquito in Africa $^{67}$. In recent reports, it was shown that the $k d r$ Leu $\rightarrow$ Phe mutation was present in a single specimen of A. arabiensis from Burkina $\mathrm{Faso}^{68}$ and two specimens from Tanzania ${ }^{58}$. The Leu Phe mutation has been found in two specimens from Uganda ${ }^{50}$ and one specimen from Kenya ${ }^{69}$. All the above specimens were heterozygous for the $k d r$ alleles and none of the reports correlate the $k d r$ alleles with resistance phenotypes. A study with colonies of A. arabiensis from Sudan was done by Matambo et al..$^{70}$ with the aim of investigation the importance of the $k d r$ mutation and potential enzyme-related resistance mechanisms in a DDT-resistant and other insecticides classes throughout of populations' generations. Exposures of F-16 generation adults to other insecticides showed a high level of resistance to all four classes of insecticides used for malaria vector control, whereas the base colony exhibited a high level of resistance to dieldrin only. All specimens from F-16 exposure DDT- strain, regardless of insecticide susceptibility phenotype, were homozygous (RR) and showed no correlation between the resistant phenotype as ascertained by bioassay and the presence of the $k d r$ mutation. 
In Sudan, Abdalla et al. ${ }^{71}$ also verify that in A. arabiensis the $1014 \mathrm{~F}$ allele was significantly associated with resistance to pyrethroids and DDT.

Due to the rapidity with which high levels of resistance to DDT it is suggested that this insecticide should be avoided for vector control interventions and underlines the need for rotational use of the other classes of insecticides to manage the situation. Pyrethroids are the only group of insecticides approved by WHO Pesticide Evaluation Scheme (WHOPES) for LLINs ${ }^{13}$.

In otherwise, Okumu et al. ${ }^{72}$ no detected $k d r$ gene mutation in wild $A$. arabiensis populations tested LLINs and IRS compounds, however the observed tolerance to pyrethroids necessitates prudence against possibility of physiological resistance arising and spreading rapidly across the area and reported the lose insecticidal efficacy with time.

Similar studies were conducted by Protopopoff et al. ${ }^{73}$ showing opposing results reporting high levels of resistance in A. gambiae populations to pyrethroids and DDT. Anopheles gambiae s.s developed phenotypic resistance to these insecticides and $k d r$ frequency has in the $A$. gambiae s.s population but was absent in A. Arabiensis. Due to selection of pyrethroids resistance is probably that A. gambiae s.s persists at high frequency in north-western Tanzania.

DDT and pyrethroids resistance are at least partially attributed to the reductions in insecticide efficacy caused by point mutations in their common target site, the voltage-gated sodium channel (VGSC), and perhaps also some sharing of metabolic resistance mechanisms ${ }^{45}$. Organophosphates and carbamates inhibit Acetylcholinesterase (AChE), an important enzyme in the central nervous system. Inhibition of AChE leads to accumulation of acetylcholine in nerve junctions (or synapses), which prevents the interruption of electrical impulse propagation ${ }^{74}$. Essandoh et al. ${ }^{75}$ revealed that absence of $119 \mathrm{~S}$ allele strongly predicted susceptibility on carbamate and organophosphate resistance in Anopheles gambiae s.s. and Anopheles coluzzii. However, Matambo et al. ${ }^{70}$ reported the inhibitory effect of the carbamate insecticide propoxur on acetylcholinesterase activity and did not show correlation with the resistant phenotype. Hemingway et al. ${ }^{76}$ recorded that larvae and adults of some samples revealed broad-spectrum organophosphate and carbamate resistance in Anopheles nigerrimus but not in Anopheles culicifacies. The authors suggested that the lack of resistance in the sample A. culicifacies probably reflects the lower levels of selection pressure of this species because of its restricted breeding sites in agricultural water.

A resistance case of multiple insecticide was reported for Qin et al. ${ }^{77}$ where Anopheles sinensis populations showed high monooxygenase and carboxylesterase activities and resistant to DDT and deltamethrin. Anopheles vagus was susceptible to deltamethrin but resistant to DDT and malathion with high monooxygenase, glutathione S-transferase and carboxylesterase activities. Low $k d r$ mutation ( $L 1014 F$ allele) and high Ace-1frequency was detected in $A$. sinensis, but no $k d r$ and Ace-1 mutation was detected in $A$. vagus populations. Aïzoun et al. ${ }^{42}$ used carbamates and organophosphate with the attempt to develop strategies that will be alternatives against pyrethroids-resistant malaria vectors in the field. These mutations were observed in A. gambiae populations that can be confers resistance to organophosphates and carbamates compounds. Chang et al. ${ }^{78}$ verified the effect of rotational use of insecticides with different modes of action in A. sinensis populations, the results showed multiple resistances to chemical insecticides, mainly long-term rotational use of various insecticides has to evolved a high insecticide resistance, being metabolic detoxification was the dominant mechanism of resistance. Nkya et al. ${ }^{79}$ detected elevate frequency in L1014Skdr mutation in A. gambiae s.s. in the urban area and in the same area showed a moderate DDT resistance in larvae and adults in populations. The link between agriculture and pyrethroids resistance was confirmed by a significant correlation between deltamethrin resistance levels and agriculture intensity across all populations. The authors discussed that both agriculture and urban areas are likely favoring the emergence of resistance to insecticides. In agriculture areas, the mainly factor is the massive usage of pesticides and in urban areas the uncontrolled indoor spraying with insecticides may strongly select for $k d r$ mutations and metabolic resistance mechanisms with a potential role of pollutants in favoring the selection of particular detoxification enzymes.

In Côte d'Ivoire a multiple-resistance of pyrethroids were reported, organochlorides and carbamate in A. Gambiae and the resistance mechanisms seem to be varied ${ }^{41,80,81}$. Ace-1 is strongly associated with organophosphate and carbamate ${ }^{81}$, but Koffi et al..$^{80}$ did not detected the L1014S $k d r$ and Ace-1R mutations, Knox et al. ${ }^{82}$ established an online tool for mapping insecticide resistance, susceptibility in major Anopheles vectors of human malaria parasites and what 
resistance mechanisms data were detected. The online platform can be accessed by IR Mapper (www.irmapper.com).

\section{Comments and Perspectives}

In American continent, the insecticide DDT was used widely, although developed countries have made use of this insecticide for much longer time. With respect to South American countries, the "technology gap" benefited somehow because it began using DDT later, thus avoiding higher concentrations in rivers and reservoirs. The use of DDT in Brazil and Latin America was mainly performed with the aim to control of malaria vectors, being $A$. darlingi as the main target, once this species is generally considered susceptible to DDT. Though, signs of resistance were detected in Colombia and Venezuela, as well as in some areas of the Brazilian Amazon, it real role but have not been sufficiently studied. It is clear that studies of resistance of $A$. darlingi in South America have been neglected and a lot remains to be done. Such that remains a possibility of have resistant strains to the current insecticides (ex: pyrethroids). There are a wide variation in the A. darlingi behavior ${ }^{83,84}$. For example in the Brazilian Amazon, reports described that some $A$. darlingi populations can modify their endophilic behavior for exophilic and anthropophilic ${ }^{85,86}$ to zoophilic, possibly caused by excito-repellency of these insecticides used in household spraying ${ }^{87}$.

The program managers have few options available when confronted with multiple-insecticide resistance and it level, reported in this review, combined with continual selection pressure will inevitably lead to suboptimal mosquito control. Other strategies of monitoring and samplings were utilize odour baits contain carbon dioxide ${ }^{88}$.

We could conclude that the resistance has spread mainly all over Africa dramatically. Use of insecticides in agriculture has been linked to resistance in malaria vectors. Although surveys of insecticide resistance are limited to a few species, the results can be alarming and can be understood that the mechanisms of resistance occurs in unstudied species of Anopheles. The rotational strategies applying a diversity insecticide classes, exploring their different modes of action is most usual, in order to decrease the probability of expressing resistance ${ }^{89}$. The rotational strategies showed successful in many applications in field showing to be effective if the resistance gene has an associated fitness $\operatorname{cost}^{90}$.

Other very important issue is how to apply these insecticides, these practices which often were made without adequate monitoring, leading to wrong handling of what and how much should be applied.

Currently it is necessary to look for others alternatives, e.g. biological control, by using other organisms as a possible regulator of the population of malaria vectors in critical outbreaks. Possibly the "biological products" appear to be undergoing laboratory tests or even define the protozoan Plasmodium as a target to these new technologies.

Products derived from plants and fungi are in constant study currently, as they offer several antagonistic activities on Anopheles mosquitoes ${ }^{91-93}$, through of crude extracts from the fungus and plants.

These kind of studies open the possibility for further investigations of the efficacy of larvicidal properties of natural product extracts and should be encouraged to find out the new products with mosquitocidal and larvicidal activities, supporting the idea that they are less harmful to the environment. 


\section{Collaborations}

GL da Silva, TN Pereira, NJ Ferla and OS da Silva participated in the elaboration of the manuscript at every stage. GL da Silva and TN Pereira worked in the writing and revision of this manuscript. OS da Silva and NJ Ferla contributed to the literature review.

\section{References}

1. Word Health Organization (WHO). WHO recommended insecticide products treatment of mosquito nets for malaria vector control. Geneva: WHO; 2007.

2. Harbach RE. The classification of genus Anopheles (Diptera: Culicidae):a working hypothesis of phylogenetic relationships. Bull Entomol Res 2004; 94(6):537553.

3. Pages F, Orlandi-Pradinesb E, Corbel V. Vecteurs du paludisme: biologie, diversité, contrôle et protection individuelle Vectors of malaria: biology, diversity, prevention, and individual protection. Med Maladies Infect 2007; 37(3):153-161.

4. Falavigna-Guilherme AL, Silva AM, Guilherme EV, Morais DL. Retrospective study of malaria prevalence and Anopheles genus in the area of influence of the binational Itaipu reservoir. Rev Inst Med Trop Sao Paulo 2005; 47(2):81-86.

5. Deane LM, Causey OR, Deane MP. Notas sobre a distribuição e a biologia dos anofelinos das regiões nordestina e amazônica do Brasil. Rev Serv Esp Saúde Publ 1948; 1(4):827-965.

6. Hiwat H, Bretas G. Ecology of Anopheles darlingi Root with respect to vector importance: a review. Parasit Vectors $2011 ; 4: 177$.

7. Sanchez-Ribas J, Parra-Henao G, Guimarães AE. Impact of dams and irrigation schemes in Anopheline (Diptera: Culicidae) bionomics and malaria epidemiology. Rev Inst Med Trop São Paulo 2012; 54(4):179191.

8. Becker N, Petric D, Zgomba M, Boase C, Madon M, Dahl C, Kaiser A. Mosquitoes and Their Control. $2^{\text {nd }}$ ed. Heidelberg: Springer-Verlag Berlin Heidelberg; 2010.

9. Besansky NJ, Hill CA, Costantini C. No accounting for taste: host preference in malaria vectors. Trends Parasitol 2004; 20(6):249-251.

10. Takken W, Knols BG. Odor-mediated behavior of Afrotropical malaria mosquitoes. Annu Rev Entomol 1999; 44:131-157.

11. Torr SJ, Della Torre A, Calzetta M, Costantini C, Vale GA. Towards a fuller understanding of mosquito behaviour: use of electrocuting grids to compare the odour-orientated responses of Anopheles arabiensis and A. quadriannulatus in the field. Med Vet Entomol 2008; 22(2):93-108.

12. Kleinschmidt I, Schwabe C, Shiva M, Segura JL, Sima V, Mabunda SJ, Coleman M. Combining indoor residual spraying and insecticide-treated net interventions. $A m$ J Trop Med Hyg 2009; 81(3):519-524.

13. West PA, Protopopoff N, Wright A, Kivaju Z, Tigererwa R, Mosha FW. Kisinza W, Rowland M, Kleinschmidt I. Indoor residual spraying in combination with insecticide-treated nets compared to insecticide-treated nets alone for protection against malaria: a cluster randomized trial in Tanzania. PLoS Med 2014; 15(4):e1001630.

14. Carson R. Silent Spring. Boston: Houghton Mifflin; 1962.

15. Khwaja MA. Study on environmental and health impacts of abandoned persistent organic pollutant (DDT) factory in North West Frontier Province (NWFP) Pakistan. SDPI Research and News Bulletin 2006; 13(4\&5):20-22. 
16. World Health Organization (WHO). Global Malaria Programme: World Malaria Report. Geneva: WHO 2011.

17. Moiroux N, Gomez MB, Pennetier C, Elanga E, Djenontin A, Chandre F, Djègbé I, Guis H, Corbel V. Changes in Anopheles funestus biting behavior following universal coverage of long-lasting insecticidal nets in Benin. J Infect Dis 2012; 206(10):1622-1629.

18. Sovi A. Govoétchan R, Tokponnon F, Hounkonnou H, Aïkpon R, Agossa F, Gnanguenon V, Salako AS, Agossou $\mathrm{C}$, Ossè $\mathrm{R}$, Okè $\mathrm{M}$, Gbénou $\mathrm{D}$, Massougbodji $\mathrm{A}$, Akogbéto M. Impact of land-use on malaria transmission in the Plateau region, southeastern Benin. Parasit Vectors 2013; 6:352.

19. Mwangangi JM, Shililu J, Muturi EJ, Muriu S, Jacob B, Kabiru EW, Mbogo CM, Githure J, Novak RJ. Anopheles larval abundance and diversity in three rice agro-village complexes Mwea irrigation scheme, central Kenya. Malar J 2010; 9:228.

20. Goonasekere KGA, Amerasinghe FP. Planning, design and operation of irrigation schemes - their impact on mosquito-borne diseases. Vector-borne disease control in humans through rice agroecosystem management. Proceedings of the workshop on Research and Training needs in the field of integrated vector borne diseases control in Rice Agroecosystem of developing countries. Los Baños: International Rice Research Institute; 1988. p. 41-50.

21. Robert V, Van de Broek A, Stevens P, Slootweg R, Petrarca V, Coluzzi M, Le Goff G, Di Deco MA, Carnevale P. Mosquitoes and malaria transmission in irrigated rice-fields in the Benoue Valley of northern Cameroon. Acta trop 1992; 52(2-3):201-204.

22. Jarju LBS, Fillinger U, Green C, Louca V, Majambere S, Lindsay SW. Agriculture and the promotion of insect pests: rice cultivation in river floodplains and malaria vectors in The Gambia. Malar J 2009; 8:170.

23. Knipple DC, Doyle KE, Marsella-Herrick PA, Soderlund DM. Tight genetic linkage between the $k d r$ insecticide resistance trait and a voltage-sensitive sodium channel gene in the house fly. Proc Natl Acad Sci 1994; 91(7):2483-2487.

24. WHO - Word Health Organization. World Malaria Report. 2014. [cited 2014 dez 14]. Available: http// www.who.int/entity/malaria/world_malaria_report_2011/9789244564403_eng.pd;

25. Santolamazza F, Calzett M, Etang J, Barrese E, Dia I, Caccone A, Donnelly MJ, Petrarca V, Simard F, Pinto J, Della Torre A. Distribution of knock-down resistance mutations in Anopheles gambiae molecular forms in west and west-central Africa. Malar J 2008; 7:74.

26. Della Torre A, Tu Z, Petrarca V. On the distribution and genetic differentiation of Anopheles gambiae s.s. molecular forms. Insect Biochem Molec Biol 2005; 35(7):755769 .

27. Williamson MS, Martinez-Torres D, Hick CA. Devonshire AL. Identification of mutations in the housefly para-type sodium channel gene associated with knockdown resistance $(k d r)$ to pyrethroid insecticides. $\mathrm{Mol}$ Genet Genomics 1996; 252(1-2):51-60.

28. Chandre F, Darrier F, Manga L, Akogbeto M, Faye O, Mouchet J, Guillet P. Status of pyrethroid resistance in Anopheles gambiae sensu lato. Bull World Health Organ 1999; 77(3):230-234.
29. Diabaté A. Evaluation de la résistance des vecteurs du paludisme vis à vis des pyréthrinöıdes au Burkina Faso [thesis]. Ouagadougou: Universit'e de Ouagadougou; 1999.

30. Ranson H, Jensen B, Vulule JM, Wang X, Hemingway J, Collins FH. Identification of a point mutation in the voltage gated sodium channel gene of Kenyan Anopheles gambiae associated with resistance to DDT and pyrethroids. Insect Mol Biol 2000; 9(5):491-497.

31. Vulule J, Beach R, Atieli F, Roberts J, Mount D, Mwangi R. Reduced susceptibility of Anopheles gambiae to permethrin associated with the use of permethrin-impregnated bednets and curtains in Kenya. Med Vet Entomol 1994; 8(1):71-75.

32. Etang J, Manga L, Chandre F, Guillet P, Fondjo E, Mimpfoundi R, Toto JC, Fontenille D. Insecticide susceptibility status of Anopheles gambiae s.l. (Diptera: Culicidae) in the Republic of Cameroon. J Med Entomol 2003; 40(4):491-497.

33. Nwane P, Etang J, Chouaibou M, Toto JC, Kerah-Hinzoumbé C, Mimpfoundi R, Awono-Ambene HP, Simard F. Trends in DDT and pyrethroid resistance in Anopheles gambiae s.s. populations from urban and agro-industrial settings in southern Cameroon. BMC Infect Dis 2009; 9:163.

34. Wang J. Resistance to two pyrethroids in Anopheles sinensis from Zhejiang, China. J Am Mosq Control Assoc 1999; 15(3):308-311.

35. Diabaté A, Baldet T, Chandre F, Guiguemdé RT, Brengues C, Guillet P, Hemingway J, Hougard JM. First report of the $k d r$ mutation in Anopheles gambiae $\mathrm{M}$ form from Burkina Faso, west Africa. Parassitologia 2002; 44(3-4):157-158.

36. Diabaté A, Brengues C, Baldet T, Dabiré K, Hougard JM, Akogbeto M, Kengne P, Simard F, Guillet P, Hemingway J, Chandre F. The spread of the Leu-Phe $k d r$ mutation through Anopheles gambiae complex in Burkina Faso: genetic introgression and de novo phenomena. Trop Med Int Health 2004; 9(12):1267-1273.

37. Etang J, Fondjo E, Chandre F, Morlais I, Brengues C, Nwane P, Chouaibou M, Ndjemai H, Simard F. First report of knockdown mutations in themalaria vector Anopheles gambiae from Cameroon. Am J Trop Med Hyg 2006; 74(5):795-797.

38. Reimer LJ, Tripet F, Slotman M, Spielman A, Fondjo E, Lanzaro GC. An unusual distribution of the $k d r$ gene among populations of Anopheles gambiae on the island of Bioko, Equatorial Guinea. Insect Mol Biol 2005; 14(6):683-688.

39. Tripet F, Wright J, Cornel A, Fofana A, McAbee R, Meneses C, Reimer L, Slotman M, Thiemann T, Dolo G, Traoré S, Lanzaro G. Longitudinal survey of knockdown resistance to pyrethroid $(k d r)$ in Mali, West Afri$\mathrm{ca}$, and evidence of its emergence in the Bamako form of Anopheles gambiae s.s.. Am J Trop Med Hyg 2007; 76(1):81-87.

40. Diabaté A, Baldet T, Chandre F, Akoobeto M, Guiguemde TR, Darriet F, Brengues C, Guillet P, Hemingway J, Small GJ, Hougard JM. The role of agricultural use of insecticides in resistance to pyrethroids in Anopheles gambiae s.l. in Burkina Faso. Am J Trop Med Hyg 2002; 67(6):617-622. 
41. Elissa N, Mouchet J, Riviere F, Meunier JY, Yao K. Resistance of Anopheles gambiae s.s. to pyrethroids in Côte d'Ivoire. Ann Soc Belg Med Trop 1993; 73(4):291-294.

42. Aïzoun N, Aïkpon R, Gnanguenon V, Oussou O, Agossa F, Padonou GG, Akogbéto M. Status of organophosphate and carbamate resistance in Anopheles gambiae sensu lato from the south and north Benin, West Africa. Parasit Vectors 2013; 6:274.

43. Corbel V, N'Guessan R, Brengues C, Chandre F, Djogbenou L, Martin T, Akogbéto M, Hougard JM, Rowland M. Multiple insecticide resistance mechanisms in Anopheles gambiae and Culex quinquefasciatus from Benin, West Africa. Acta Trop 2007; 101(3):207-216.

44. Ranson H, Abdallah H, Badolo A, Guelbeogo WM, Kerah-Hinzoumbé C, Yangalbé-Kalnoné E, Sagnon N, Simard F, Coetzee M. Insecticide resistance in Anopheles gambiae: data from the first year of a multi-country study highlight the extent of the problem. Malar J 2009; 8:299.

45. Martinez-Torres D, Chandre F, Williamson MS, Darriet F, Berge JB, Devonshire AL, Guillet P, Pasteur N, Pauron D. Molecular characterization of pyrethroid knockdown resistance $(k d r)$ in the major malaria vector Anopheles gambiae s.s. Insect Mol Biol 1998; 7(2):179-184.

46. Kabula B, Kisinza W, Tungu P, Ndege C, Batengana B, Kollo D, Malima R, Kafuko J, Mohamed M, Magesa S. Co-occurrence and distribution of East (L1014S) and West (L1014F) African knock-down resistance in Anopheles gambiae sensu lato population of Tanzania. Trop Med Int Health 2014; 19(3):331-341.

47. Gentile G, Santolamazza F, Fanello C, Petrarca V, Caccone A, Della Torre A. Variation in an intron sequence of the voltage-gated sodium channel gene correlates with genetic differentiation between Anopheles gambiae s.s. molecular forms. Insect Mol Biol 2004; 13(4):371-377.

48. Fanello C, Petrarca V, Della Torre A, Santolamazza F, Dolo G, Coulibaly M, Alloueche A, Curtis CF, Touré YT, Coluzzi M. The pyrethroid knock-down resistance gene in the Anopheles gambiae complex in Mali and further indication of incipient speciation within $A$. gambiae s.s. Insect Mol Biol 2003; 12(3):241-245.

49. Weill M, Chandre F, Brengues C, Manguin S, Akogbeto M, Pasteur N, Guillet P, Raymond M. The kdr mutation occurs in the Mopti form of Anopheles gambiae s.s. through introgression. Insect Mol Biol 2000; 9(5):451455.

50. Verhaeghen K, Van Bortel W, Roelants P, Backeljau T, Coosemans M. Detection of the East and West African $k d r$ mutation in Anopheles gambiae and Anopheles arabiensis from Uganda using a new assay based on FRET/ Melt Curve analysis. Malar J 2006; 5:16.

51. Weissmann G. DDT is back: let us spray! Faseb J 2006; 20(14):2427-2429.

52. Chareonviriyaphap T, Roberts DR, Andre RG, Harlan HJ, Languins S, Bangs MJ. Pesticide avoidance behavior in Anopheles albimanus, a malaria vector in the Americas. J Am Vet Med 1997; 13(2):171-183.

53. Lol JC, Castellanos ME, Liebman KA, Lenhart A, Pennington PM, Padilla NR. Molecular evidence for historical presence of knock-down resistance in Anopheles albimanus, a key malaria vector in Latin America. Parasit Vectors 2013; 6:268.
54. Xu T, Zhong D, Tang L, Chang X, Fu F, Yan G, Zheng B. Anopheles sinensis mosquito insecticide resistance: comparison of three mosquito sample collection and preparation methods and mosquito age in resistance measurements. Parasit Vectors 2014; 7:54.

55. Awolola ST, Adeogun AO, Olojede JB, Oduola AO, Oyewole IO, Amajoh CN. Impact of PermaNet 3.0 on entomological indices in an area of pyrethroid resistant Anopheles gambiae in south-western Nigeria. Parasit Vectors 2014; 7:236.

56. Pinto J, Lynd A, Vicente JL, Santolamazza F, Randle NP, Gentile G, Moreno M, Simard F, Charlwood JD, Rosário VE, Caccone A, Della Torre A, Donnelly MJ. Multiple Origins of Knockdown Resistance Mutations in the Afrotropical Mosquito Vector Anopheles gambiae. PLoS ONE 2007; 2(11):e1243.

57. Ilboudo-Sanogo E, Badolo A, Guelbeogo WM, Sagnon $\mathrm{N}$, Sirima SB. Insecticide Resistance in Malaria Vectors in Areas of Seasonal Malaria Transmission in Burkina Faso: Knock-Down Resistance Gene Distribution. $\mathrm{Ma}$ lar Chemoth Cont Elimination 2013; 2(1):1-8.

58. Kulkarni MA, Rowland M, Alifrangis M, Mosha FW, Matowo J, Malima R, Peter J, Kweka E, Lyimo I, Magesa S, Salanti A, Rau ME, Drakeley C. Occurrence of the leucine-to-phenylalanine knockdown resistance $(k d r)$ mutation in Anopheles arabiensis populations in Tanzania, detected by a simplified high-throughput SSOP-ELISA method. Malar J 2006; 5:56.

59. Corbel V, Akogbeto M, Damien GB, Djenontin A, Chandre F, Rogier C, Moiroux N, Chabi J, Banganna B, Padonou GG, Henry MC. Combination of malaria vector control interventions in pyrethroid resistance area in Benin: a cluster randomized controlled trial. Lancet Infect Dis 2012; 12(8):617-626.

60. Briët OJT, Penny MA, Hardy D, Awolola TS, Bortel WV, Corbel V, Dabiré RK, Etang J, Koudou BG, Tungu PK, Chitnis N. Effects of pyrethroid resistance on the cost effectiveness of a mass distribution of long-lasting insecticidal nets: a modelling study. Malar J 2013; 12:77.

61. Ndiath MO, Mazenot C, Sokhna C, Trape J-F. How the Malaria Vector Anopheles gambiae Adapts to the Use of Insecticide-Treated Nets by African Populations. PLoS ONE 2014; 9(6):e97700.

62. Word Health Organization (WHO). World Malaria Report. Geneva: WHO; 2008.

63. Suarez MF, Quiñones ML, Palacios JD, Carrillo A. First record of DDT resistance in Anopheles darlingi. J Am Mosq Control Assoc 1990; 6(1):72-74.

64. Santos JB, Dos Santos F, Macêdo V. Variation of Anopheles density with deltamethrin-impregnated mosquito nets in an endemic malaria area of the Brazilian Amazon. Cad Saude Publica 1999; 15(2):281-292.

65. Magris M, Rubio-Palis Y, Alexander N, Ruiz B, Galván $\mathrm{N}$, Frias D, Blanco M, Lines J. Community-randomized trial of lambdacyhalothrin-treated hammock nets for malaria control in Yanomami communities in the Amazon region of Venezuela. Trop Med Int Health 2007; 12(3):392-403.

66. Naice MV. Expressão de genes de resistência a inseticidas em A. darlingi Root, 1926 (Diptera: Culicidae) de Coari-AM, em condições de estresse químico [dissertação]. Manaus: INPA; 2010. 
67. Gillies MT, Coetzee M. A Supplement to the Anophelinae of Africa South of the Sahara (Afrotropical Region). of the Research. Johannesburg: South African Institute for Medical; 1987. Publication no 55.

68. Diabaté A, Baldet T, Chandre F, Dabiré KR, Simard F, Ouedraogo JB, Guillet P, Hougard JM. First report of a $k d r$ mutation in Anopheles arabiensis from Burkina Faso, West Africa. J Am Mosq Control Assoc 2004; 20(2):195-196.

69. Stump AD, Atieli FK, Vulule JM, Besansky NJ. Dynamics of the pyrethroid knockdown resistance allele in western Kenyan populations of Anopheles gambiae in response to insecticide-treated bed net trials. Am J Trop Med Hyg 2004; 70(6):591-596.

70. Matambo TS, Abdalla HA, Brooke BD, Koekemoer MA, Hunt RH, Coetz M. Insecticide resistance in the malarial mosquito Anopheles arabiensis and association with the $k d r$ mutation. Med Vet Entomol 2007; 21(1):97-102.

71. Abdalla H, Wilding CS, Nardini L, Pignatelli P, Koekemoer LL, Ranson H, Coetzee M. Insecticide resistance in Anopheles arabiensis in Sudan: temporal trends and underlying mechanisms. Parasit Vectors 2014; 7:213.

72. Okumu FO, Chipwaza B, Madumla EP, Mbeyela E, Lingamba G, Moore J, Ntamatungro AJ, Kavishe DR, Moore SJ. Implications of bio-efficacy and persistence of insecticides when indoor residual spraying and long-lasting insecticide nets are combined for malaria prevention. Malar J 2012; 11:378.

73. Protopopoff N, Matowo J, Malima R, Kavishe R, Kaaya R, Wright A, West PA, Kleinschmidt I, Kisinza W, Mosha FW, Rowland M. High level of resistance in the mosquito Anopheles gambiae to pyrethroid insecticides and reduced susceptibility to bendiocarb in north-western Tanzania. Malar J 2013; 12:149.

74. Braga IA, Valle D. Aedes aegypti: inseticidas, mecanismos de ação e resistência. Epid Serv Saúde 2007; 16(4):279-293.

75. Essandoh J, Yawson AE, Weetman D. Acetylcholinesterase (Ace-1) target site mutation 119S is strongly diagnostic of carbamate and organophosphate resistance in Anopheles gambiae s.s. and Anopheles coluzzii across southern Ghana. Malar J 2013; 12:404.

76. Hemingway J, Jayawardena KG, Herath PR. Pesticide resistance mechanisms produced by field selection pressures on Anopheles nigerrimus and A. culicifacies in Sri Lanka. Bull World Health Organ 1986; 64(5):753-758.

77. Qin Q, Li Y, Zhong D, Zhou N, Chang X, Li C, Cui L, Yan G, Chen X-G. Insecticide resistance of Anopheles sinensis and A. vagus in Hainan Island, a malaria-endemic area of China. Parasit Vectors 2014; 7:92.

78. Chang X, Zhong D, Fang Q, Hartsel J, Zhou G, Shi L, Fang F, Zhu C, Yan G. Multiple Resistances and Complex Mechanisms of Anopheles sinensis Mosquito: A Major Obstacle to Mosquito-Borne Diseases Control and Elimination in China. PLoS Negl Trop Dis 2014; 8(6):e2889.

79. Nkya TE, Akhouayri I, Poupardin R, Batengana B, Mosha F, Magesa S, Kisinza W, David JP. Insecticide resistance mechanisms associated with different environments in the malaria vector Anopheles gambiae: a case study in Tanzania. Malar J 2014; 13(1):28.

80. Koffi AA, Alou LPA, Adja MA, Chandre F, Pennetier C. Insecticide resistance status of Anopheles gambiae s.s population from M’Bé: a WHOPES-labelled experimental hut station, 10 years after the political crisis in Côte d'Ivoire. Malar J 2013; 12(1):151.
81. Edi CVA, Koudou BG, Jones CM, Weetman D, Ranson H. Multiple-Insecticide Resistance in Anopheles gambiae Mosquitoes, Southern Côte d'Ivoire. Emerg Infect Dis 2012; 18(9):1508-1511.

82. Knox TB, Juma EO, Ochomo EO, Jamet HP, Ndungo L, Chege P, Bayoh NM, N'Guessan R, Christian RN, Hunt $\mathrm{RH}$, Coetzee M. An online tool for mapping insecticide resistance in major Anopheles vectors of human malaria parasites and review of resistance status for the Afrotropical region. Parasit Vectors 2014; 7:76.

83. Charlwood JD, Hayes J. Variações geográficas no ciclo de picada do Anopheles darlingi Root no Brasil. Acta Amazonica 1978; 8(4):601-603.

84. Roberts DR, Alecrim WD, Tavares AM, Radke MG. The house-frequenting, host seeking and resting behavior of Anopheles darlingi in southeastern Amazonas, Brazil. J Am Mosq Control Assoc 1987; 3(3):433-441.

85. Lourenço-de-Oliveira R, Guimarães AEG, Arlé M, Silva TF, Castro MG, Motta MA, Deane LM. Anopheline species, some of their habits and relation to malaria in endemic areas of Rondonia State, Amazon region of Brazil. Mem Inst Oswaldo Cruz 1989; 84(4):501-514.

86. Klein TA, Lima JBP. Seasonal distribution and biting patterns of Anopheles mosquitoes in Costa Marques, Rondonia, Brazil. J Am Mosq Control Assoc 1990; 6(4):700-707.

87. Roberts DR, Chareonviriyaphap T, Harlan HH, Hshieh P. Methods of testing and analyzing excito-repellency responses of malaria vectors to insecticides. J Am Mosq Control Assoc 1997; 13(1):13-17.

88. Mweresa CK, Omusula P, Otieno B, Van Loon JJA, Takken W, Mukabana WR. Molasses as a source of carbon dioxide for attracting the malaria mosquitoes Anopheles gambiae and Anopheles funestus. Malar J 2014; 13:160.

89. Curtis CF. Theoretical models of the use of insecticide mixtures for management of resistance. Bull Ent Res 1985; 75(2):259-265.

90. Insecticide Resistance Action Commitee (IRAC). Prevention and Management of Insecticide Resistance in Vectors of Public Health Importance. In: Resistance Management for Sustainable Agriculture and Improved Public Health. $2^{\text {nd }}$ ed. IRAC; 2010. 72 p.

91. Bagavan A, Rahuman AA. Evaluation of larvicidal activity of medicinal plant extracts against three mosquito vectors. Asian Pac J Trop Med 2011; 4(1):29-34.

92. Govindarajan M, Sivakumar R, Rajeswary M, Yogalakshmi K. Chemical composition and larvicidal activity of essential oil from Ocimum basilicum (L.) against Culex tritaeniorhynchus, Aedes albopictus and Anopheles subpictus (Diptera: Culicidae). Experimental Parasitology 2013; 134(1):7-11.

93. Kamaraj C, Rahuman AA, Bagavan A, Elango G, Zahir AA, Santhoshkumar T. Larvicidal and repellent activity of medicinal plant extracts from Eastern Ghats of South India against malaria and filariasis vectors. Asian Pac J Trop Med 2011; 4(9):698-705.

Artigo apresentado em 03/12/2014

Aprovado em 09/06/2015

Versão final apresentada em 11/06/2015 